\title{
The Nexus between Corporate Social Responsibility Disclosure and Financial Performance: Evidence from the Listed Banks, Finance and Insurance Companies in Sri Lanka
}

\author{
J. Aloy Niresh ${ }^{1} \&$ Dr. W. H. E. Silva ${ }^{2}$ \\ ${ }^{1}$ Lecturer, Department of Finance and Accountancy, Faculty of Business Studies, Vavuniya Campus of the \\ University of Jaffna, Sri Lanka \\ ${ }^{2}$ Senior Lecturer, Department of Accounting, Faculty of Management Studies \& Commerce, University of Sri \\ Jayewardenepura, Sri Lanka \\ Correspondence: J. Aloy Niresh, Lecturer, Department of Finance and Accountancy, Faculty of Business Studies, \\ Vavuniya Campus of the University of Jaffna, Sri Lanka
}

Received: January 02, 2018

Accepted: January 22, 2018

Online Published: January 31, 2018

doi:10.5430/afr.v7n2p65

URL: https://doi.org/10.5430/afr.v7n2p65

\begin{abstract}
The nexus between Corporate Social Responsibility Disclosure (CSRD) and financial performance is an ongoing debate and a puzzle encountered by business organizations. This study is an attempt to address the question of whether CSRD is linked to financial performance of companies quoted on the Banks, Finance and Insurance sector in Sri Lanka. The sample includes only the companies that devote a separate section to disclose Corporate Social Responsibility (CSR) activities in their annual reports as failure to disclose CSR in the annual reports will have a material effect on findings. Corporate Financial Performance (CFP) is measured through the use of Return on Assets (ROA) and Return on Equity (ROE) controlled for size and leverage. Content analysis was utilized to develop the Corporate Social Responsibility Disclosure Index (CSRDI). Two multiple regression models were analyzed using Stata. Findings of the study revealed that there is a significant association between Corporate Social Responsibility Disclosure and future financial performance of the selected listed banks, finance and insurance companies in Sri Lanka.
\end{abstract}

Keywords: CSRD, CSRDI, CFP, ROA, ROE, Content analysis

\section{Introduction}

Corporate Social Responsibility (CSR) is increasingly becoming popular as organizational performance is not merely measured by financial performance. CSR is considered as the indicator of social performance as most of the organizations realized this and started creating a separate report called sustainability report to show how they contribute to the betterment of society. Business organizations have become aware of the importance of presenting information about the broader range of activities including both their financial performance and non-financial performance such as corporate social performance (Aksik and Gal, 2011).

The role of business in society has experienced a noteworthy makeover in the last few decades. While businesses have been given progressively more autonomy, they have also been held responsible for a range of issues that were formerly considered the sole responsibility of the government (Tilakasiri, 2012). The primary goal of the organizations is to maximize profit. However, that should not be at the expense of society's well-being. According to Carroll (1991), organization's accountability is to act in a socially responsible manner and this will not only be lucrative but also will be to obey the rule, to be moral, and to be a good corporate inhabitant. The business paradigm has changed from maximization of shareholders' wealth to maximization of stakeholders' wealth in the present era. Since it is almost the responsibility of all the organizations irrespective of the nature of their business to practice CSR so as to keep their business viable and sustainable for long.

Profitability is no longer the key factor driving business success. Instead, social and environmental standards determine a company's ability to reap profits. In the light of this, it is imperative to ascertain the status of Sri Lankan firms and their preparedness for facing challenges of doing business in the future in a world which is increasingly more networked and has seen a shift of power from governments and corporates, to the people that make up society. 
This study intends to learn the direction of association between CSR disclosure and financial performance of the listed firms belong to the Banks, Finance and Insurance sector in Sri Lanka. It is assumed a direct relationship between CSR disclosure and financial performance exists with a one-year lag between predictor variables and financial performance in this study.

In the post financial crisis context of 2008 that dragged down the world's economy, activities connected to corporate social responsibility (CSR) is a remedy that companies seek to improve their reputation (Burianova and Paulik, 2014). Many companies, especially in the banking industry, have lost their credibility in the eyes of the consumers as the crisis emanated from the financial markets. People's trust towards banks with their money and investment eroded, halting the growth of economy. CSR has been found to be a way for companies in the banking industry to earn back their credibility (Cornett et al. 2014). Complex activities practiced by the banks are too intricate for the general public who are not familiar with the operations of that field, which is why it is important to illustrate to the people that they care about the society with activities that people understand about. In addition, increased customer awareness exert more pressure to companies to not only look good but to also act well (Yeung, 2011).

In light of the essence of the study, this will be of great value to the body of knowledge in the field of CSR discipline and will form the basis for further researches by identifying the gap that arises from this study. Moreover, the findings of this study will be helpful to the managers of companies especially the financial intermediaries to get to know how they can best utilize CSR practices to boost financial performance. At last, this study will definitely be useful for scholars and academic researchers to understand more of the information on the nexus between CSR disclosure and financial performance hence resulting in addition of more information to the existing pool of knowledge.

\section{Literature Review}

\subsection{Theoretical Underpinnings}

There are numerous philosophies to explain the reasons why corporations involve in corporate social responsibility. These include, stakeholder theory, institutional theory, political economy theory, legitimacy theory, stewardship theory and agency theory. However, the engagement in CSR cannot be explained merely by using a single theory. This study is predominantly directed towards applying stakeholder theory in arriving at the findings.

\subsubsection{Stakeholder Theory}

Stakeholder theory is concerned with the relationship between an organization and its stakeholders. Central in stakeholder theory is the idea that the success of a company depends on the extent to which the company is able of managing its relationships with stakeholder groups, such as financiers, shareholders, customers, employees, and communities or societies (Van Beurden et al. 2008). Freeman (1984) defines stakeholders as "any group or individual who is affected by or can affect the achievement of an organization's objectives". Stakeholder theory suggests that an organization must appease not only explicit claims or contracts (e.g. claims from shareholders), but also implicit claims or contracts (McGuire et al. 1988, p. 854) as well. Explicit contracts legally describe the relationship between a firm and its stakeholders, while implicit contracts have no legal status and are referred to as self-enforcing relational contracts (Ruf et al. 2001). In other words, stakeholder theory focuses on the necessity for organizations to deliberate on the needs, the interests, and the influence of all stakeholders, which eventually influences the organizations' end result.

\subsection{Studies related to Corporate Social Responsibility Disclosure and Financial Performance in Emerging Countries}

Weber (2017) analyzed the connection between sustainability performance of Chinese banks and their financial indicators to explore whether sustainability regulations can be implemented without decreasing the financial performance of banking sector. Annual reports and websites were used as the source of data and the researcher came to know that corporate sustainability performance and financial performance are not a trade-off but correlate positively. Further, bi-directional causality between financial performance and sustainability performance of Chinese banks has been found.

Elif and Halil (2017) conducted a study to identify the relationship between firm performance and corporate social responsibility (CSR) of firms listed on Borsa Istanbul during the period of 2009-2011. The study used content analysis of annual reports/websites of Turkish firms for any socially responsible activities. The study found a negative relationship between CSR and financial performance, implying that firms which disclose more information about CSR initiatives in their annual reports have a lower return on assets. 
Dakito (2017) used a mixed research approach and applied multivariate econometric model to assess the relationship between CSR and Banks' financial performance in Ethiopia. The finding shows that, there is no relationship between the financial contribution for CSR activities and CFP. On the other hand, the descriptive analysis shows even if the top managements in the banking sector have awareness about CSR, a lot of improvements are expected from firms in the Ethiopia to discharge their CSR properly since majority of the business firms in the country are in the lower layer of Carroll's 1991 CSR pyramid.

Tanveer et al. (2017) conducted a study to discover the impact of CSR on financial performance (FP) of banking sector of Pakistan, using a sample of 30 commercial banks listed on the Pakistan stock exchange for the period of 10 years from 2006 to 2015. Pooled regression models were applied to investigate the impact of CSR on FP. Empirical findings signify the robustness of pooled model that documented a positive and significant impact of CSR on return on assets, return on equity and earnings per share. This premise holds that CSR has positive and significant impact on FP of selected commercial banks of Pakistan.

Joseph and Michah (2016) examined the impact of corporate social responsibility on financial performance of listed banks in Nigeria for the period ranging from 2010 to 2014. The Impact of EPS, ROCE and DPS was tested on CSR. Simple regression analysis was employed by the researchers in testing the data collected from the annual published financial statements of the selected banks. The regression result showed that EPS and DPS have negative significant relationship with CSR while ROCE has a positive significant relationship with CSR.

Haque and Azmat (2015) conducted a case study to examine the state of corporate social responsibility in labor-intensive industries in developing countries in the context of economic globalization. Ready-made garment (RMG) industry has been selected as the sample and findings were arrived at by reviewing the extant literature and content analysis of two leading newspapers in Bangladesh for a period of one year (July 2012 to June 2013). The findings suggest that non-compliance of CSR in labor-intensive industries is a function of the nature of economic globalization. Further, the study emphasized the need for stakeholder approach towards CSR for the profitability and sustainability in the RMG industry.

Ehsan and Kaleem (2012) conducted a study with the intention of finding the association between CSR and financial performance of 100 quoted manufacturing firms in Pakistan. Donations and employee welfare funds were utilized as the dimensions of CSR based on which CSR data was constructed. The authors found a positive association between CSR disclosure and financial performance using panel data analysis. ROA, ROE and EPS were insignificantly linked with CSR whereas negative association was observed between firms' growth and CSR.

Tilakasiri (2012) examined the nexus between CSR disclosure and financial performance in the Sri Lankan context. Data was gathered using content analysis and the researcher utilized 28 CSR check-list items. Fifty companies listed on the Colombo Stock Exchange (CSE) were used as sample for a period of six years from 2004 to 2009. The empirical findings reveal that there is a positive association between CSR disclosure and financial performance. Pertaining to the dimensions of CSR, community disclosure was significantly and positively associated with ROE and ROA. Further, negative association was observed between health related activities and performance measures of ROA and ROE.

Mulyadi et al. (2012) studied the empirical relation between CSR to firm value and profitability in Indonesia in 2010. 30 listed Indonesian corporations were examined using double linear regression model. They found that there is no noteworthy relationship between CSR and firm value and same evidence for CSR and profitability. Moreover, Abiodun (2012) studied the relationship between CSR and firm profitability in Nigeria by way of using ordinary least square method as a tool for data analysis. The result showed a negative relationship between firm profitability and CSR, implies profitable organizations in Nigeria do not invest much in CSR activities.

The association between CSR disclosure and earnings per share was investigated by Kwanbo (2011) using content analysis. Data was sourced from annual reports of 231 companies quoted on the Nigerian stock exchange for the period from 2005 to 2009. The study found no impact of CSR disclosure on financial performance (EPS) of Nigerian companies. However, significant relationship was observed between CSR disclosure and firm size in terms of number of employees and number of shareholders.

To probe the link between CSR disclosure and financial performance as expressed by ROA, ROE, and Tobin's Q, Choi et al. (2010) constructed a stakeholder-weighted CSR index and equal- weighted (EW) CSR index from seven categories of Korea Economic Justice Institute (KEJI) index scores. Financial data from TS-2000 database was utilized for the period from 2002 to 2008 . The results indicate a significant positive relationship between stakeholder weighted CSR index and three financial performance measures. Further, remarkable positive association was observed between EW-CSR disclosure and ROA and stakeholder-weighted CSR index had a positive impact on financial performance of 
the firms.

Mittal et al. (2008) conducted a study to examine the relationship between Economic Value Added (EVA) and CSR practices of the firms in India using content analysis. Data was sourced from fifty corporate annual reports over a period of five years to identify the extent of CSR disclosure practices. A negative relationship was observed between CSR and EVA in three out of five years. For the latter two years, the association between CSR and EVA was found to be positive and insignificant. Further, a weak positive association was identified between CSR and Market Value Added (MVA).

Wickramasinghe (2006) examined the effect and relationship of CSR on the success of selected manufacturing companies in Sri Lanka. Economic, employee, product, environment, discrimination and community factors were considered as the dimensions of CSR and company success was measured using Return on Investment (ROI). There is a significant positive relationship between the success of the selected companies and the level of social responsibility in Sri Lankan companies, findings reveal. Economic and employee concerns are the key social issues that affect a company's performance. Consequently, environmental, discrimination and community involvement were ignored.

\subsection{Research Gaps Arising from the Literature}

CSR is principally considered as a western marvel owing to the strong institutions, standards and appeal systems of the emerged nations, which are not robust in emerging countries (Chapple and Moon, 2005). Such non-robust standards pose a considerable challenge to the companies practicing CSR in developing countries, including Sri Lanka. The relationship between CSR and financial performance has provoked much interest among researchers especially in the developed countries. The extant literature from Sri Lanka reveals the existence of lack of knowledge and awareness of CSR among the Sri Lankan firms (Fernando, 2007). It is an indication that majority of the Sri Lankan companies lag behind the global best CSR practices and there is a necessity to upgrade the level of CSR practices in Sri Lanka. The evidence exists for CSR engagement in Sri Lanka, but the empirical examination of the relationship between CSR and corporate financial performance is scant (Wijesinghe and Senaratne, 2011). The lack of empirical studies on this issue could be the root cause in explaining why Sri Lankan companies are less concerned in promoting their CSR activities. Businesses will not pay attention unless they know the benefits of practicing CSR. Thus, by using CSRD as measurement of CSR practice, this study is an effort to fill the gap by empirically examining the link between CSRD and financial performance at the industry level in Sri Lanka.

The study is directed towards identifying the CSR practices and the relationship between CSR disclosures and financial performance of the listed companies which lie under the Banks, Finance and Insurance Sector in Sri Lanka. The banking sector is a distinctive business in society and its role nowadays goes far beyond bringing financial stability to the economy; it now involves launching new trends and strategies, providing necessary services for customers and reducing financial exclusion. The banking sector is at the heart of society and thus it is expected to be more socially answerable (Chambers and Day, 2009). The numbers of exploratory researches were found to be scant when it comes to discover the association between CSR disclosure and financial performance in the field of banking, a neglected area in the CSR literature in Sri Lanka.

Wijesinghe and Senaratne (2011) conducted a study on the impact of CSR disclosure on corporate financial performance in Banks, Finance and Insurance sector in Sri Lanka based on the GRI framework. GRI is considered as a common framework and it cannot be regarded as a perfectly fitted model framework for a country like Sri Lanka. Because what is pertinent for a developed nation might not be pertinent for a developing country like Sri Lanka. To alleviate this, the present study adopted a CSR framework that is tailored to fit for the Sri Lankan context as it can be considered as an all-encompassing model framework applicable for the Sri Lankan context.

According to Emerson (2003), the level of devotion and interpretation of CSR varies within companies and across industries. Further, Beurden and Gossling (2008) felt the need of an industry-specific study, which assists in the evolvement of CSR research further. Because, each industry can have different contexts, environment and stakeholder expectations which might impact findings. Sting Consultants, Sri Lanka reveals that the number of companies practicing CSR is relatively high in Banks, Finance and Insurance sector as compared to other sectors. All these things add value to the selection of Banks, Finance and Insurance sector as the choice of study. Abiding by these suggestions our research therefore, focuses on industry specific study based on the listed companies belong to the Banks, Finance and Insurance sector in Sri Lanka. 


\section{Methodology}

\subsection{Conceptual Framework}

In this study, corporate social responsibility disclosure has been utilized as explanatory variable and financial performance as measured by Return on Assets (ROA) and Return on Equity (ROE) have been utilized as outcome variables. As control variables, firm size as measured by log of total assets and leverage as measured by debt to total funds ratio were utilized. Based on the variables used in the study, the conceptual model has been formed in the following manner.

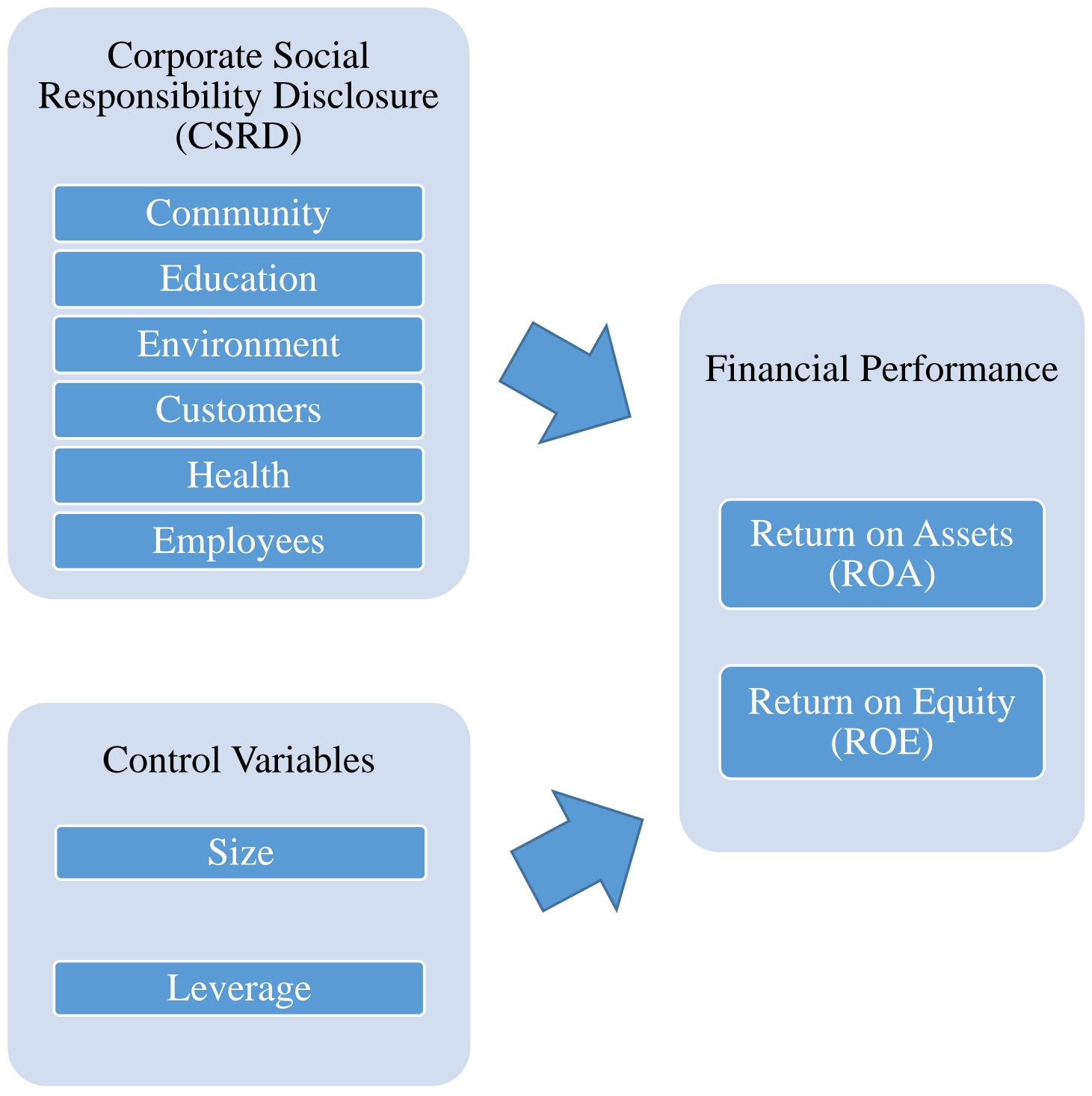

Figure 1. Conceptual Model

Source: Deduced from the literature

\subsection{Operationalization}

Operationalization is the process of defining variables into measurable factors. The process defines incoherent concepts and allows them to be measured, empirically and quantitatively. The detailed description for the operationalization of variables is tabulated as follows: 
Table 1. Operationalization of variables used in the study

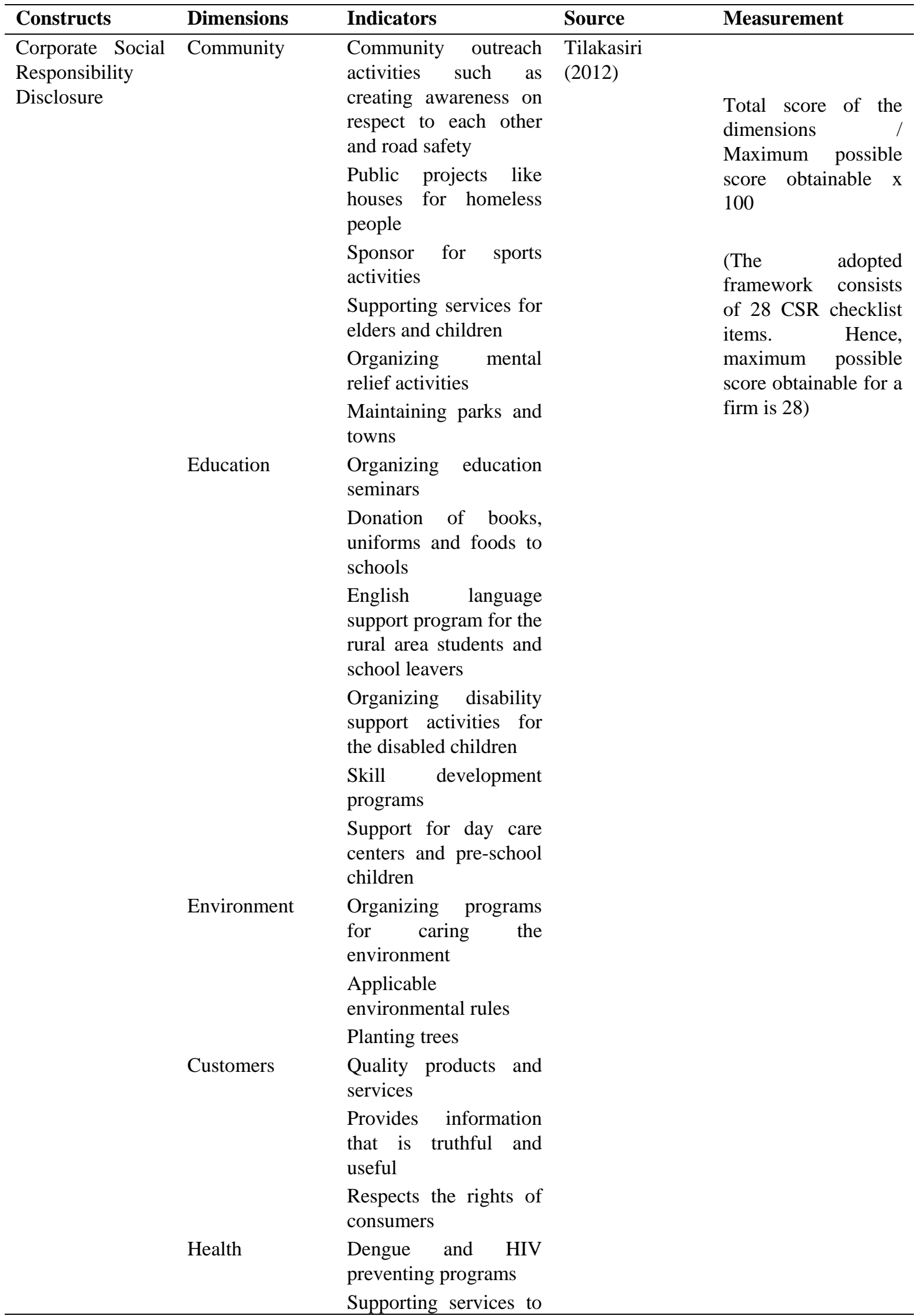




\begin{tabular}{|c|c|c|c|c|}
\hline & \multirow{4}{*}{ Employees } & \multicolumn{3}{|l|}{ government hospitals } \\
\hline & & \multicolumn{3}{|l|}{$\begin{array}{l}\text { Scholarships to the } \\
\text { medical students for } \\
\text { further education }\end{array}$} \\
\hline & & \multicolumn{3}{|l|}{$\begin{array}{l}\text { Training } \\
\text { development }\end{array}$} \\
\hline & & \multicolumn{3}{|l|}{$\begin{array}{l}\text { Health and safety } \\
\text { programs }\end{array}$} \\
\hline & & \multicolumn{3}{|l|}{$\begin{array}{l}\text { Trade } \\
\text { development }\end{array}$} \\
\hline & & \multicolumn{3}{|l|}{$\begin{array}{l}\text { Employee } \\
\text { benefits-insurance, } \\
\text { share option plans }\end{array}$} \\
\hline & & \multicolumn{3}{|l|}{$\begin{array}{l}\text { Formal recruiting, } \\
\text { promotion and firing } \\
\text { system }\end{array}$} \\
\hline & & \multicolumn{3}{|l|}{$\begin{array}{l}\text { Equal employment } \\
\text { opportunity }\end{array}$} \\
\hline & & \multicolumn{3}{|l|}{$\begin{array}{l}\text { Disclosing policy on } \\
\text { company's } \\
\text { remuneration schemes }\end{array}$} \\
\hline \multirow{3}{*}{$\begin{array}{l}\text { Financial } \\
\text { Performance }\end{array}$} & \multirow{3}{*}{$\begin{array}{l}\text { Accounting } \\
\text { based measures }\end{array}$} & \multirow[t]{2}{*}{ Return on Assets } & Peters and & Earnings before \\
\hline & & & $\begin{array}{l}\text { Mullen } \\
\text { (2009); Moneva } \\
\text { and Ortas } \\
(2010) ; \quad \text { Jitaree } \\
(2015) ; \\
\text { Tilakasiri, } \\
(2012)\end{array}$ & $\begin{array}{l}\text { Interest and Tax } \\
(\text { EBIT) / Average } \\
\text { Total Assets x } 100\end{array}$ \\
\hline & & Return on Equity & $\begin{array}{lr}\text { Griffin } & \text { and } \\
\text { Mahon } & (1997) ; \\
\text { Moneva } & \text { and } \\
\text { Ortas } & (2010) ; \\
\text { Lyon } & (2007) ; \\
\text { Ghelli } & (2013) ; \\
\text { Tilakasiri, } \\
\text { (2012) }\end{array}$ & $\begin{array}{l}\text { Net income } \\
\text { Shareholders' funds } \\
\text { x } 100\end{array}$ \\
\hline \multirow[t]{2}{*}{$\begin{array}{l}\text { Firm specific } \\
\text { characteristics }\end{array}$} & Size & Total Assets & $\begin{array}{l}\text { Chen and Wang } \\
(2011) \text {; Mishra } \\
\text { and } \\
(2010) \text {; } \\
\text { Clarkson et al. } \\
(2011)\end{array}$ & Log of Total Assets \\
\hline & Leverage & $\begin{array}{l}\text { Debt to Total Funds } \\
\text { ratio }\end{array}$ & $\begin{array}{l}\text { Nelling and } \\
\text { Web (2009); } \\
\text { Brammer and } \\
\text { Pavelin (2006); } \\
\text { Waddock and } \\
\text { Graves (1997); } \\
\text { D'Arcimoles } \\
\text { and Trebucq } \\
(2002)\end{array}$ & $\begin{array}{l}\text { Interest bearing debts } \\
\text { / Total funds } x 100\end{array}$ \\
\hline
\end{tabular}




\subsection{Sample Design and Data Collection}

\subsubsection{Sample Design}

The target population of the study is the number of firms which belong to the Banks, Finance and Insurance sector. The selection of the sample for this study is restricted to those firms who disclosed the information in relation to sustainability over the years from 2010 to 2014 . Hence, purposive sampling method has been utilized so as to select the sample from target population. As a result, 33 companies were selected as sample for this study.

\subsubsection{Data Collection}

Secondary data has been utilized in this study and the observed data consists of six-year period from 2010 to 2015. Information in relation to CSR was obtained from the companies' annual reports over the years from 2010 to 2014 and the data with regard to companies' financial performance was collected over the years from 2011 to 2015.

Annual reports were predominantly used to collect the data required for the study. The information contained in the annual reports has the power to influence the readers since which are read by almost all the stakeholders (Deegan and Rankin, 1997). According to Tilt (1994), annual reports are the most common medium for CSR disclosures and for obtaining information on a firm. In line with this, Holland and Foo (2003) stated that organizations are gradually using annual reports for disclosing information on their social actions. Most vital tool used by companies to connect with their stakeholders is the annual reports and thus reflect the responsibility discharge activity of companies. Furthermore, they are widely distributed and often directly available on the companies' websites. However, there are disadvantages too using of annual reports as a source of data collection. The first and foremost disadvantage is that organizations might potentially deceive the users of annual reports to nurture a better public image. Thus, the information exposed in annual reports can differ from real corporate activities (Turker, 2008). If so, the published annual reports will lose their credibility by not showing the real picture of the organizations and any findings based on such information will be open to debate.

\subsection{Formulation of Hypotheses}

It is generally expected to be a positive relationship between CSR disclosure and financial performance according to the stakeholder theory. In this study, the researchers try to show that some causality is related to lagging between periods for CSRD and financial performance. This study builds upon the notion that there may exist a relationship between CSR, risk level, firm size and profitability.

Scholars have proposed various opinions about how a company's social performance may impact its end result. The largest number of investigations found a positive association between corporate social responsibility and corporate financial performance (Simpson and Kohers, 2002; Margolis and Walsh, 2003; Ortlizky et al. 2003; Tilakasiri, 2012). Contrary to this, Moore (2001) found a negative temporaneous relationship between CSR disclosure and financial performance. Nelling and Webb (2009) used KLD index as the measure of CSR and ROA as the measure of financial performance found no evidence that CSR is related to firms' performance. There is still considerable debate about the nature of this relationship (Doh et al., 2010; Van Beurden and Gossling, 2008) and much more remains to be understood about this relationship (Choi and Wang, 2009; Coombs and Gilley, 2005). Hence, there is no single established theoretical foundation with a clear empirical prediction as to how corporate social responsibility disclosure is related with corporate financial performance.

\subsubsection{Corporate Social Responsibility Disclosure and Financial Performance}

In this study, it is hypothesized that there is a positive relationship between CSR disclosure and financial performance as measured by ROA and ROE. This assumption is based on prior studies that predicted a directional positive relationship between CSRD and corporate financial performance (Tilakasiri, 2012; Wijesinghe and Senaratne, 2011; Tsoutsoura, 2004; Ruf et al. 2001; Waddock and Graves, 1997).

This study utilizes one-year lag for the independent variables, which explores the relationship between social disclosure and future financial performance. The use of this time lag is consistent with Waddock and Graves, 1997; Tsoutsoura, 2004; Dahaliwal et al. 2011; Tilakasiri, 2012; Mahoney and Roberts, 2007 in their tests of the potential relationship between corporate social performance and future financial performance. Since the predictors were used as lagged variables, the hypotheses in relation to CSRD and financial performance were formed based on the conception that better CSR performance leads to better future financial performance of selected listed banks, finance and insurance companies in Sri Lanka. 
The following hypotheses were formulated for the study:

$\mathrm{H}_{1}$ : There is a significant positive association between corporate social responsibility disclosure and financial performance as measured by ROA.

$\mathrm{H}_{2}$ : Corporate social responsibility disclosure and financial performance as measured by ROE are significantly and positively correlated.

Both these hypotheses imply that banks, finance and insurance companies which disclose CSR in the current year will experience increased financial performance in the subsequent year.

\subsection{Research Model}

The study follows the panel model specification for the purpose of estimating whether involvement in CSR enhances the bottom line of the sampled firms in Sri Lanka. The panel data model is of the following form:

$Y_{\text {it }}=\alpha_{i}+\beta_{1} X_{1 \text { it- } 1}+\beta_{2} X_{2 \text { it- } 1}+\beta_{3} X_{3 \text { it- }-1}+\varepsilon_{\text {it }-1}$

Where $Y_{i t}$ is the performance of firm $i$ at time $t, \alpha_{i}$ is a constant term, $\beta_{1}$ and $\beta_{2}$ are the beta coefficients, $X_{1}, X_{2}$ and $X_{3}$ are the explanatory variables and control variables used in the study, and $\varepsilon_{\mathrm{it}-1}$ is the error term.

Based on the hypotheses formulated, the specific models to be tested are as follows:

$\operatorname{ROA}_{\mathrm{it}}=\alpha_{\mathrm{i}}+\beta_{1} \operatorname{CSRD}_{\mathrm{it}-1}+\beta_{2} \operatorname{Size}_{\mathrm{it}-1}+\beta_{3} \operatorname{Lev}_{\mathrm{it}-1}+\varepsilon_{\mathrm{it}-1}($ Model 1)

$\operatorname{ROE}_{\mathrm{it}}=\alpha_{\mathrm{i}}+\beta_{1} \mathrm{CSRD}_{\mathrm{it}-1}+\beta_{2} \operatorname{Size}_{\mathrm{it}-1}+\beta_{3} \mathrm{Lev}_{\mathrm{it}-1}+\varepsilon_{\mathrm{it}-1}($ Model 2)

In the above models, a composite measure is constructed as a CSR index and this is incorporated in to the models together with all the control variables. The aforementioned models were formed to test the hypotheses 1 and 2 respectively.

\subsection{Statistical Analysis}

Depending on the nature of the data, statistical tools can be used for different purposes. As statistical tools, measures of central tendency and panel data models - Fixed Effects Model (FEM) and Random Effects Model (REM) were employed to arrive at the findings of the study. For the data analysis, statistical analysis program - Stata 14.2 was used in this study.

\subsubsection{Panel data Analysis}

Since the study involves both, cross sectional and time series components, longitudinal study is considered to be the most appropriate approach in this paper. Generalized Least Square models viz Fixed and Random Effects Models were employed to arrive at the findings of the study. There are two reasons associated with the selection of GLS over Ordinary Least Square (OLS). First is, even though the pooled OLS model produces consistent estimates of the regression estimates, there are chances for understated standard errors and consequently overstated significance levels. The latter reason is, compared to the GLS model, the OLS as an estimation method does not result in efficient estimates of the regression coefficients (Johnston and DiNardo, 1997).

\subsubsection{Hausman Test: FEM vs REM}

Hausman test is employed to decide between fixed and random effects. It basically tests whether the unique errors are correlated with the regressors. If error component $\left(\mu_{\mathrm{i}}\right)$ is correlated with any explanatory variables, the random effects estimator is inconsistent, while the fixed effects estimator remains consistent. The test compares the co-efficient estimates from the Random Effects Model to those from the Fixed Effects Model. The following hypotheses were tested while applying Hausman test.

$\mathrm{H}_{0}$ : There is no significant difference between co-efficient estimates.

$\mathrm{H}_{1}$ : There is a significant difference between co-efficient estimates.

If the chi2 $\left({ }_{2} 2\right)$ value is significant, $\mathrm{H}_{1}$ will be supported. It implies that there is a significant difference between co-efficient estimates. Hence, this will lead to the rejection of random effects estimator.

\subsubsection{Cross-sectional Dependence}

Panel-data models are likely to exhibit substantial cross-sectional dependence in the errors, which may arise due to omitted common effects, spatial effects, or could arise as a result of interactions within socio economic networks (Pesaran, 2004). Panel estimators such as fixed or random effects can result in misleading inference and even inconsistent estimators, depending on the extent of cross-sectional dependence and on whether the source generating the cross-sectional dependence is correlated with regressors (Sarafidis and Robertson, 2009). 
Testing for cross-sectional dependence is important in fitting panel-data models. When $\mathrm{T}>\mathrm{N}$, one may use for these purposes the Lagrange Multiplier (LM) test, developed by Breusch and Pagan (1980). On the other hand, when T < $\mathrm{N}$, the LM test statistic enjoys no desirable statistical properties in that it exhibits substantial size distortions. Thus, there is clearly a need for testing for cross sectional dependence in Stata when $\mathrm{N}$ is large and $\mathrm{T}$ is small - the most commonly encountered situation in panels.

\subsubsection{Pesaran CD Test}

The following hypotheses were tested while applying this test:

$\mathrm{H}_{0}$ : Residuals are not correlated.

$\mathrm{H}_{1}$ : Residuals are correlated.

The significant $\mathrm{p}$ value $(\mathrm{p}<0.05)$ will lead to the rejection of null hypothesis, implying that residuals are correlated.

\section{Analysis}

\subsection{Testing of the Association between Corporate Social Responsibility Disclosure and Financial Performance}

This section presents the results of the panel data analysis employed by the researchers using Fixed Effects Method and Random Effects Method. These two estimates are compared to find the best model using Hausman test which was discussed in methodology.

\subsubsection{Testing of the Association between CSRD and ROA}

Table 2 presents the findings of the multiple regressions of the association between CSRD and ROA as outcome variable.

Table 2. Panel data analysis - CSRDI and ROA as the outcome variable

\begin{tabular}{|c|c|c|c|}
\hline \multirow[b]{2}{*}{ Variables } & & \multicolumn{2}{|l|}{ Model 1} \\
\hline & & Fixed Effects Model & Random Effects Model \\
\hline \multirow[t]{2}{*}{ Constant } & & $-48.7766^{* * * *}$ & -7.6963 \\
\hline & & $(-4.41)$ & $(-1.38)$ \\
\hline \multirow{2}{*}{$\begin{array}{l}\text { Corporate } \quad \text { Social } \\
\text { Disclosure Index }\end{array}$} & Responsibility & $0.0657^{* * *}$ & $0.0923^{* * *}$ \\
\hline & & $(3.87)$ & $(5.79)$ \\
\hline \multirow[t]{2}{*}{ Log of Total Assets } & & $0.0456^{* * *}$ & 0.0065 \\
\hline & & $(4.33)$ & $(1.16)$ \\
\hline \multirow[t]{4}{*}{ Leverage } & & 0.0289 & -0.0028 \\
\hline & & $(1.28)$ & $(-0.15)$ \\
\hline & & $\mathrm{R}^{2}=0.43$ & $\mathrm{R}^{2}=0.38$ \\
\hline & & F-statistic $=32.98^{* * *}$ & Wald Chi2 $=64.57^{* * *}$ \\
\hline
\end{tabular}

Hausman test $\left(\chi^{2}\right)$

$$
21.18^{* * *}
$$

Notes: $\mathrm{t}$ statistics are reported in parentheses

$$
\begin{aligned}
& * \quad \text { Indicate significant at } 10 \% \text { level }(\mathrm{P}<0.1) \\
& * * \quad \text { Indicate significant at } 5 \% \text { level }(\mathrm{P}<0.05) \\
& * * * \quad \text { Indicate significant at } 1 \% \text { level }(\mathrm{P}<0.01)
\end{aligned}
$$

The results of the regression estimates in the table 2 show the relationship between CSRDI and financial performance as measured by ROA. As it can be seen from the table that the results of the Hausman test confirms that individual effects were correlated with the regressors in the model since the Chi2 value was found to be statistically significant. Hausman test result shows that random effects are biased. Hence, the FEM is preferred over REM.

It is apparent from the table 2 that the overall model (FEM) is significant at $\mathrm{P}<0.01$. The $\mathrm{R}^{2}$ value for the FEM is 0.43 , implying that $43 \%$ of the variations in ROA are explained by the variations in the predictor variables namely 
CSRDI, log of total assets and leverage. The coefficient for the association between CSRD and ROA is observed to be 0.0657 and which is statistically significant at $1 \%$ level.

In terms of control variables, it was found that there is no statistically significant association between leverage as measured by debt total funds ratio and ROA. But firm size as measured by log of total assets showing a significant positive association with ROA with a coefficient value of 0.0456 .

\subsubsection{Testing of the relationship between CSRD and ROE}

Table 3 presents the results obtained from the regression analysis between CSRD and ROE as the dependent variable.

Table 3. Panel data analysis - CSRDI and ROE as the outcome variable

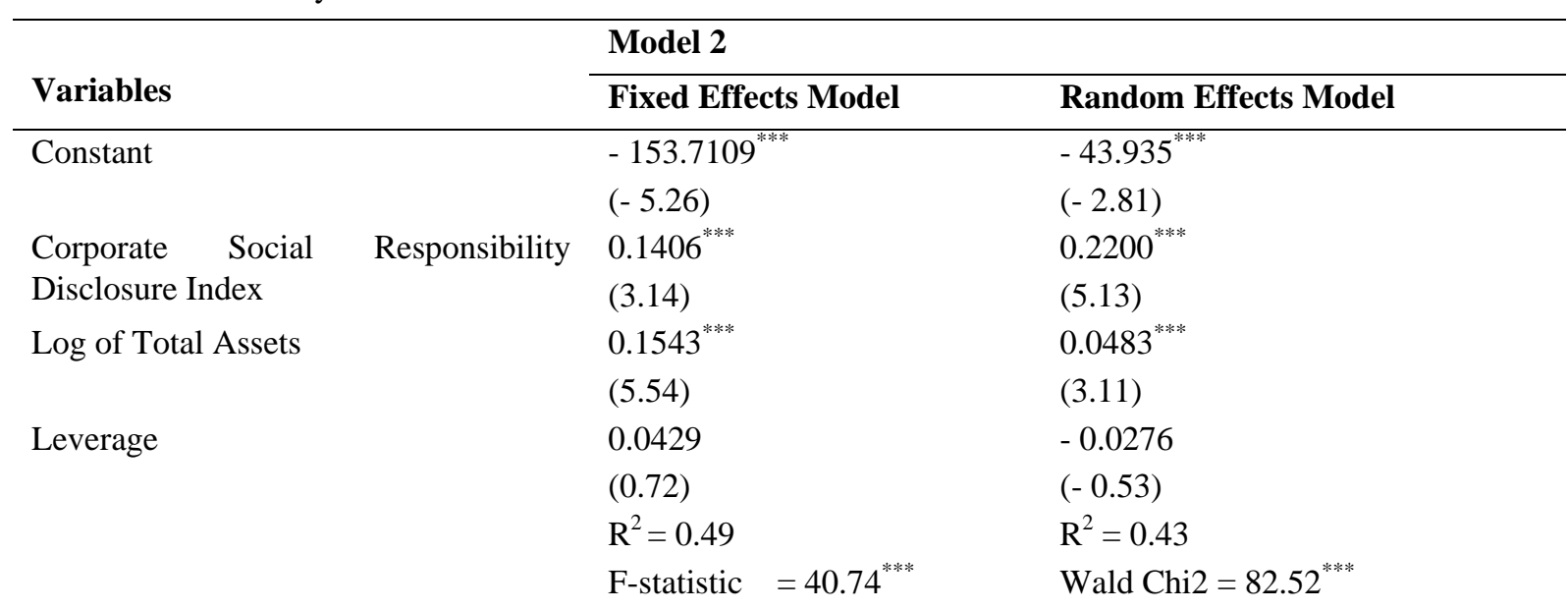

Hausman test $\left(\chi^{2}\right)$

$$
45.94^{* * *}
$$

Notes: $\mathrm{t}$ statistics are reported in parentheses

$$
\begin{aligned}
& * \quad \text { Indicate significant at } 10 \% \text { level }(\mathrm{P}<0.1) \\
& * * \quad \text { Indicate significant at } 5 \% \text { level }(\mathrm{P}<0.05) \\
& * * * \text { Indicate significant at } 1 \% \text { level }(\mathrm{P}<0.01)
\end{aligned}
$$

It is apparent from the table 3 that FEM is preferred over REM since the result of the Hausman test shows Chi2 ( 2 ) value of 45.94 , which is statistically significant at 0.01 level. It is an indication that unobserved individual effects were correlated with the regressors. Therefore, it can be inferred that FEM is more precise than REM.

The empirical results shown in the table 3 indicate a statistically significant positive association between corporate social responsibility disclosure and future financial performance as measured by ROE. The overall model is significant at $\mathrm{P}<0.01$ and explains that $49 \%$ of the variations in $\mathrm{ROE}$ are caused by the variations in the predictors namely CSRD, log of total assets and leverage.

As far as the association between control variables and ROE is concerned, leverage exhibits a positive association with ROE but the coefficient value of 0.0429 is statistically insignificant. It is an indication that there is no significant association between leverage and ROE. Contrary to this, log of total assets shows a positive relationship

\begin{tabular}{|c|c|c|c|c|c|c|}
\hline Hypotheses & $\begin{array}{l}\text { Relationship } \\
\text { between }\end{array}$ & $\begin{array}{l}\text { FEM or } \\
\text { REM }\end{array}$ & Coefficient & $P$ value & $\begin{array}{l}\text { Decision } \\
\text { criteria }\end{array}$ & $\begin{array}{l}\text { Supported or } \\
\text { Not } \\
\text { supported }\end{array}$ \\
\hline $\mathrm{H}_{1}$ & CSRD and ROA & FEM & 0.0657 & 0.000 & $\mathrm{P}<0.01$ & Supported \\
\hline $\mathrm{H}_{2}$ & CSRD and ROE & FEM & 0.1406 & 0.002 & $\mathrm{P}<0.01$ & Supported \\
\hline
\end{tabular}
with ROE with a statistically significant coefficient value of 0.1543 at 0.01 level.

\subsection{Testing of Hypotheses}

Table 4. Testing of hypotheses 
By referring to the table 4, it is apparent that both the hypotheses viz $\mathrm{H}_{1}$ and $\mathrm{H}_{2}$ were supported in the study. CSRD is positive and significantly associated with both the outcome variables - ROA and ROE. It is an indication that the increase in the level of disclosure will lead to an increase in the subsequent financial performance.

\subsection{Testing of Cross Sectional Dependence}

The following table shows the outcomes of the Pesaran's cross sectional dependence test:

Table 5. Results of Pesaran's cross sectional dependency test

\begin{tabular}{lll}
\hline Description & $\begin{array}{l}\text { Model 1 } \\
\text { (FEM) }\end{array}$ & $\begin{array}{l}\text { Model 2 } \\
\text { (FEM) }\end{array}$ \\
\hline Pesaran's test of cross sectional independence & 1.141 & 0.821 \\
Probability (Pr) & 0.2540 & 0.4117 \\
\hline
\end{tabular}

By referring to the table 5 it is obvious that no cross sectional dependency was found across the companies in the preferred models used for the study. The $\mathrm{P}$ values are recognized to be statistically insignificant at all the levels. The null hypothesis is supported in all the models used for the study implying that residuals are not correlated. Hence, there is enough evidence suggesting the non-presence of cross sectional dependence in the ideal models used for the study.

\subsection{Testing for Multicollinearity}

The present study employed Variance Inflation Factor (VIF) test in order to identify whether the problem of multicollinearity exists in the study. The VIF indicates whether a predictor has a strong linear relationship with other predictors. Related to the VIF is the tolerance statistics, which is its reciprocal (1/VIF). There are no hard and fast rules about what value of the VIF should be the cause for concern, but generally a VIF value of greater than 10 indicates a serious problem (Bowerman and O'Conell, 1990; Myers, 1990). Further, if the average VIF is substantially greater than one then the regression may be biased. As far as the value of tolerance is concerned, tolerance below 0.1 indicates a serious problem (Menard, 1995).

The study involved 2 models and in the model 1 and 2 CSRDI, log of total assets and leverage were combined together to assess their connectivity with financial performance using ROA and ROE.

\subsubsection{Testing of Multicollinearity: CSRDI, Log of Total Assets and Leverage as Predictors}

This section presents the collinearity statistics when CSRDI, log of total assets and leverage were used as predictors. The following VIF and tolerance values were derived at by employing the VIF test as tabulated in the table 6 .

Table 6. VIF and tolerance statistics - CSRDI, log of total assets and leverage as predictors

\begin{tabular}{|c|c|c|}
\hline Predictors & $\begin{array}{ll}\text { Variance } & \text { Inflation } \\
\text { Factor (VIF) } & \end{array}$ & Tolerance (1/VIF) \\
\hline Corporate Social Responsibility Disclosure Index & 1.35 & 0.74 \\
\hline Log of total assets & 1.41 & 0.71 \\
\hline Leverage & 1.15 & 0.87 \\
\hline Mean VIF & 1.30 & \\
\hline
\end{tabular}

By referring to the table 6 , it is apparent that there is no strong evidence of multicollinearity in the models 1 and 2 used for the study. The VIF values are less than 10 and the mean VIF is not considerably larger than 1 confirm that the models are not suffering from the problem of multicollinearity.

\section{Implications of the Findings}

This study tests the stakeholder approach to CSR and makes a contribution to the theory and corporate social responsibility disclosure and financial performance literature in the following manner.

The study developed a conceptual model based on the two aspects of stakeholder theory named descriptive aspect and instrumental aspect to examine the association between corporate social responsibility disclosure and financial performance (Donaldson and Preston, 1995). This study used the descriptive aspect for identifying the key stakeholders who have an effect on the association between the levels of corporate social responsibility disclosure and organizational performance. Instrumental aspect focuses on the cause and effect relationships between 
stakeholder management practices and corporate performance (Marom, 2006). The instrumental aspect is inferred from the proposition that practicing stakeholder management will improve organizational performance.

This study provides insights into the relationship between corporate social responsibility disclosure and financial performance and tested whether this relationship at the industry level in the Sri Lankan context is positive, negative or neutral. Thus, this research makes an important contribution to the growing body of literature in the area of corporate social responsibility disclosure and financial performance especially in the context of banks, finance and insurance companies in emerging countries.

The findings of this research give a strong impetus to the listed banks, finance and insurance companies in Sri Lanka to increase the level of corporate social responsibility disclosure as evidence of a positive relationship between CSRD and future financial performance is provided through this research. Therefore, managers can make use of CSR as a tool for increasing the long-run performance of organizations. The global investment community is also increasingly considering corporate responsibility in their investment decisions through socially responsible investment. Global investors have discerned the link between sustainability performance and financial performance, as well as the comprehensive risk management of companies operating responsibly. A growing number of investors only invest in companies that have shown to be operating in a responsible and sustainable manner.

\section{Conclusion}

The future of business is intrinsically linked to strategic corporate responsibility. CSR can take three forms namely philanthropic CSR, transactional CSR and transformational CSR. Organizations are increasingly moving towards transformational CSR now which has seen a shift from charity driven CSR to strategy driven CSR (Tilakasiri, 2012). It enables organizations to internalize a culture of corporate responsibility into their core business operations. The main purpose of CSR is to manage stakeholder relationships to ensure that business operations give rise to significant long-term benefits for them, whilst at the same time minimizing the negative impacts that are created due to daily business activities.

The study is aimed at testing the link between corporate social responsibility disclosure and financial performance of the listed firms which belong to the Banks, Finance and Insurance sector in Sri Lanka. The findings reveal that there is a significant relationship between CSRD and financial performance when the latter is measured in terms of Return on Assets and Return on Equity. Hence, it can be inferred that CSRD is likely to be associated with better future financial performance. There is a growing body of evidence that CSR activities influence economic performance of companies (Waddock and Graves, 1997; Tsoutsoura, 2004; Wijesinghe and Senaratne, 2011; Tilakasiri, 2012). Managers of organizations can make use of CSR as a tool to increase organizational performance. Therefore, the objectives of companies such as profit maximization could be achieved through active participation of managers in CSR practices. Further, this result can be used as an essential piece of information to the companies especially in the Banks, Finance and Insurance industry which have to be more agile in their involvement in CSR activities and also in its disclosure.

The regulating bodies of corporates in Sri Lanka for example Colombo Stock Exchange (CSE), Ceylon Chamber of Commerce (CCC) and Securities and Exchange Commission encourage companies to adopt sustainability principles in their core business operations. The code of best practice on corporate governance issued by CSE and Securities and Exchange Commission provides the foundation for the business organizations in Sri Lanka based on which the sustainability principles can be built upon. Even though, it is not mandated implies that corporates are encouraged to report on sustainability. Further, the CCC annually awards the "Best Corporate Citizen" award to firms which excel at CSR. Hence, there are adequate mechanisms in place to motivate companies to adopt sustainability in their core business operations in Sri Lanka.

Regulations are ever-increasing in various forms worldwide. Sri Lanka is no exception as well. This cannot be considered great news for companies as regulations provide a perimeter to the possibilities for innovation and companies will have to comply. Further, CSR is deemed a voluntary activity and stakeholders expect the organizations to report beyond the statutory boundaries of reporting. Therefore, even when laws and regulations are intact, the true outcomes of CSR, in whatsoever the form, cannot be realized if the organizations limit their reporting based on laws and regulations.

\section{Future Research Directions}

The study proffers the following for further research: Some limitations of this research should be investigated in the future research. The data required for this study is sourced from annual reports. Future research could include other means of reporting to look into the extent of CSR disclosure and its relationship with financial performance. Because, 
companies report CSR activities in other medias too for example newspapers, promotional leaflets, websites and brochures. The information from other means of communication may show a comprehensive image of CSR disclosure in the Sri Lankan context and more specifically in the context of Banks, Finance and Insurance companies. This study is restricted to two financial performance indicators and no indicators were utilized in relation to market performance. Hence, future studies could add more insight into this thought by adding market based indicators. Further, this study is limited to the listed firms which belong to the Banks, Finance and Insurance sector in Sri Lanka. Therefore, further researches can be done by differentiating sector. The sample size is assumed to be small and it limits the generalizability of the findings to Sri Lanka. Therefore, it could be taken to the next level by widening the number of firms included in the study.

\section{References}

Abdul Rahman, SA, Yusoff, R \& Wan Mohamed, WN. (2009). Environmental disclosure and financial performance: an empirical study of Malaysia, Thailand and Singapore. Social and Environmental Accountability Journal, 29(2), 46-58. https://doi.org/10.1080/0969160X.2009.9651811

Adams, CA. (2002). International organizational factors influencing corporate social and ethical reporting: Beyond current theorizing. Accounting, Auditing and Accountability Journal, 15(2), 223-250. https://doi.org/10.1108/09513570210418905

Akisik, O \& Gal, G. (2017). The impact of corporate social responsibility and internal controls on stakeholders' view of the firm and financial performance. Sustainability Accounting, Management and Policy Journal, 8(3), 246-280. https://doi.org/10.1108/SAMPJ-06-2015-0044

Aksik, O \& Gal, G. (2011). Sustainability in business, corporate social responsibility, and accounting standards: An empirical study. International Journal of Accounting and Information Management, 19(3), 304-324. https://doi.org/10.1108/18347641111169287

Alsaeed, K. (2006). The association between firm specific characteristics and disclosure: The case of Saudi Arabia. Managerial Auditing Journal, 21(5), 476-496. https://doi.org/10.1108/02686900610667256

Barbosa, N \& Louri, H. (2005). Corporate performance: does ownership matter? A comparison of foreign and domestic owned firms in Greece and Portugal. Review of Industrial Organization, 27, 73-112. https://doi.org/10.1007/s11151-005-4920-y

Barnett, ML \& Salomon, RM. (2006). Beyond dichotomy: The curvilinear relationship between social responsibility and financial performance. Strategic Management Journal, 27, 1101-1122. https://doi.org/10.1002/smj.557

Barnett, ML \& Salomon, RM. (2012). Does it pay to be really good? Addressing the shape of the relationship between Social and Financial Performance. Strategic Management Journal, 33, 1304-1320. https://doi.org/10.1002/smj.1980

Bayoud, NS, Kavanagh, M \& Slaughter, G. (2012). An empirical study of the relationship between corporate social responsibility disclosure and organizational performance: evidence from Libya. International Journal ofManagement and Marketing Research, 5(3), 69-82.

Beddewela, ES \& Khan, F. (2006). Corporate Social Responsibility Practices: A comparative study of local and multinational companies in Sri Lanka. Sri Lankan Journal of Management, 13, 1-21.

Burianova, L. \& Paulik, J. (2014). Corporate Social Responsibility in Commercial Banking, A Case Study from the Czech Republic. Journal of competitiveness, 6(1), 50-70.

Campbell, JL. (2007). Why would corporations behave in socially responsible ways? An institutional theory of corporate social responsibility. Academy of Management Review, 32(3), 946-967. https://doi.org/10.5465/AMR.2007.25275684

Carroll, AB. (1979). A three-dimensional conceptual model of corporate performance. The Academy of Management Review, 4(4), 497-505.

Carroll, AB. (1991). The pyramid of corporate social responsibility: toward the moral management of organizational stakeholders. Business Horizons, 34(4), 39-48. https://doi.org/10.1016/0007-6813(91)90005-G

Carroll, AB. (1999). Corporate social responsibility: evolution of a definitional construct. Business and Society, 38(3), 268-295. https://doi.org/10.1177/000765039903800303 
Carroll, AB. (2000). A commentary and an overview of key questions on corporate social performance measurement. Business and Society, 39(4), 466-478. https://doi.org/10.1177/000765030003900406

Carroll, AB. (2008). A History of Corporate Social Responsibility. The Oxford Handbook on Corporate Social Responsibility. Oxford University Press, 19-46.

Chen, H and Wang, X. (2011). Corporate social responsibility and corporate financialperformance in China: an empirical research from Chinese firms. Corporate Governance, 11(4), 361-370. https://doi.org/10.1108/14720701111159217

Cheung, P \& Mak, W. (2010). The relation between corporate social responsibility disclosure and financial performance: Evidence from the commercial banking industry. Unpublished Master of Financial Risk Management thesis, Simon Fraser University.

Choi, JS, Kwak, YM \& Choe, C. (2010). Corporate socialresponsibility and corporate financial performance: evidence from Korea. Australian Journal of Management, 35(3), 291-311.

Clarkson, PM, Overell, MB \& Chapple, L. (2011). Environmental reporting and its relation to corporate environmental performance. Abacus, 47(1), 27. https://doi.org/10.1111/j.1467-6281.2011.00330.x

Cochran, PL \& Wood, RA. (1984). Corporate social responsibility and financial performance. The Academy of Management Journal, 27(1), 42-56. https://doi.org/10.2307/255956

Coombs, J \& Gilley, K. (2005). Stakeholder management as a predictor of CEO compensation: Main effects and interactions with financial performance. Strategic Management Journal, 26(9), 827-840. https://doi.org/10.1002/smj.476

Crane, A, McWilliams, A, Matten, D, Moon, J, \& Siegel, D. (2008). Corporate social responsibility agenda. The Oxford handbook of corporate social responsibility, 3-15.

D'Arcimoles, CH \& Trebucq, S. (2002). The corporate social performance - financial performance link: evidence from France. working paper series.

Dakito, AK. (2017). The Impact of Corporate Social Responsibility Practices on Financial Performance of Banking Sector in Ethiopia. Global Journal of Management and Business Research, 17(1).

Deegan, C. (2000). The triple bottom line What the good guys are putting in the annual report. Journal of the Securities Institute of Australia, 3, 12-14.

Deegan, C. (2002). The legitimizing effect of social and environmental disclosures: A theoretical foundation. Accounting, Auditing \& Accountability Journal, 15(3), 282 - 311. https://doi.org/10.1108/09513570210435852

Deegan, C \& Blomquist, C. (2006). Stakeholder influence on corporate reporting: an exploration of the interaction between WWF-Australia and the Australian minerals industry. Accounting, Organizations and Society, 31(4-5), 343-372. https://doi.org/10.1016/j.aos.2005.04.001

Dietrich, A \& Wanzenried, G. (2011). Determinants of Bank profitability before and during the crisis: Evidence from Switzerland. Journal of International Financial Markets, Institutions and Money, 21, 307-327. https://doi.org/10.1016/j.intfin.2010.11.002

Dkhili, H \& Ansi, H. (2012). The link between corporate social responsibility and financial performance: The case of the Tunisian companies. Journal of Organizational Knowledge Management, 11.

Donaldson, T \& Preston, LE. (1995). The stakeholder theory of the corporation: Concepts, evidence, and implications. The Academy of Management Review, 20(1), 65-91.

Ehsan, S \& Kaleem, DA. (2012). An empirical investigation of the relationship between corporate social responsibility and financial performance: evidence from manufacturing sector of Pakistan. Journal of Basic and Applied Scientific Research, 2(3), 2909-2922.

Elif, AS \& Halil, K. (2017). Corporate Social Responsibility and Firm Performance: Evidence from an Emerging Market. Accounting and Finance Research, 6(4), 42-51. https://doi.org/10.5430/afr.v6n4p42

Elijido-Ten, E. (2004). Determinants of environmental disclosure in a developing country: an application of stakeholder theory. Paper presented to the Asia Pacific Interdisciplinary Research in Accounting (APIRA), Singapore, July. 
Eng, LL \& Mak, YT. (2003). Corporate governance and voluntary disclosure. Journal of Accounting and Public Policy, 22(4), 325-345. https://doi.org/10.1016/S0278-4254(03)00037-1

Fernando, AAJ, \& Pandey, IM. (2012). Corporate social responsibility reporting: A survey of listed Sri Lankan companies. Journal for International Business and Entrepreneurship Development, 6(2), 172-187. https://doi.org/10.1504/JIBED.2012.048569

Fernando, M. (2007). Corporate Social Responsibility in the Wake of the Asian Tsunami: A Comparative Case Study of Two Sri Lankan Companies. European Management Journal, 25(1), 1-10. https://doi.org/10.1016/j.emj.2006.12.001

Fernando, M. (2010). Corporate Social Responsibility in the Wake of the Asian Tsunami: Effect of time on the genuineness of CSR initiatives. European Management Journal, 28(1), 68-79. https://doi.org/10.1016/j.emj.2009.08.002

Griffin, JJ \& Mahon, JF. (1997). The corporate social performance and corporate financial performance debate. Business \& Society, 36(1), 5-31. https://doi.org/10.1177/000765039703600102

Haque, MZ \& Azmat, F. (2015). Corporate social responsibility, economic globalization and developing countries. Sustainability Accounting, Management and Policy Journal, 6(2), 166-189. https://doi.org/10.1108/SAMPJ-04-2014-0028

Inoue, Y \& Lee, S. (2011). Effects of different dimensions of corporate social responsibility on corporate financial performance in tourism-related industries. Tourism Management, 32(4), 790-804. https://doi.org/10.1016/j.tourman.2010.06.019

Jitaree, W. (2015). Corporate social responsibility disclosure and financial performance: evidence from Thailand. Doctor of Philosophy thesis, School of Accounting, Economics and Finance, University of Wollongong.

Johnston, J \& DiNardo, J. (1997). Econometrics Method. Fourth Edition, McGraw-Hill, New York, NY.

Joseph, UM \& Michah, CO. (2016). Impact of Corporate Social Responsibility on Financial Performance: Evidence from Listed Banks in Nigeria. Expert Journal of Finance, 4, 1-9.

Kapopoulos, P \& Lazaretou, S. (2007). Corporate ownership structure and firm performance: evidence from Greek firms. Corporate Governance: An International Review, 15(2), 144-158. https://doi.org/10.1111/j.1467-8683.2007.00551.x

Kimbro, MB \& Melendy, SR. (2010). Financial performance and voluntaryenvironmental disclosures during the Asian Financial Crisis: the case of Hong Kong. International Journal of Business Performance Management, 12(1), 72-85. https://doi.org/10.1504/IJBPM.2010.036042

Kwanbo, ML. (2011). An assessment of the effectiveness of social disclosure on earnings per share in Nigerian public corporations. World Journal of Social Sciences, 1(1), 86-106.

Lee, S \& Heo, CY. (2009). Corporate social responsibility and customer satisfaction among US publicly traded hotels and restaurants. International Journal of Hospitality Management, 28(4), 635-637. https://doi.org/10.1016/j.ijhm.2009.02.007

Li, Q, Luo, W, Wang, Y \& Wu, L. (2013). Firm performance, corporate ownership, and corporate social responsibility disclosure in China. Business Ethics: A European Review, 22(2), 159-173. https://doi.org/10.1111/beer.12013

Lyon, D. (2007). Financial performance: the motivation behind corporate social responsibility reporting. Bachelor of Commerce with Honours, University of Otago.

Margolis, JD \& Walsh, JP. (2003). Misery loves companies: rethinking social initiatives by business. Administrative Science Quarterly, 48(2), 268-305. https://doi.org/10.2307/3556659

Marom, IY. (2006). Toward a unified theory of the CSP-CFP link. Journal of Business Ethics, 67(2), 191-200. https://doi.org/10.1007/s10551-006-9023-7

Marquis, C \& Qian, C. (2014). Corporate social responsibility reporting in China: symbol or substance? Organization Science, 25(1), 127-148. https://doi.org/10.1287/orsc.2013.0837

McGuire, J, Sundgren, A \& Schneeweis, T. (1988). Corporate social responsibility and firm financial performance. Academy of Management Journal, 31(4), 854-872. https://doi.org/10.2307/256342 
McWilliams, A \& Siegel, D. (2001). Corporate social responsibility: a theory of the firm perspective. Academy of Management Review, 26(1), 117-127.

Mishra, S \& Suar, D. (2010). Does corporate social responsibility influence firm performance of Indian companies? Journal of Business Ethics, 95(4), 571-601. https://doi.org/10.1007/s10551-010-0441-1

Mittal, RK, Sinha, N \& Singh, A. (2008). An analysis of linkage between economic value added and corporate social responsibility. Management Decision, 46(9), 1437-1443. https://doi.org/10.1108/00251740810912037

Moneva, JM \& Ortas, E. (2010). Corporate environmental and financial performance: a multivariate approach. Industrial Management \& Data Systems, 110(2), 193-210. https://doi.org/10.1108/02635571011020304

Nelling, E \& Webb, E. (2009). Corporate social responsibility and financial performance: the virtuous circle revisited. Review of Quantitative Finance and Accounting, 32, 197-209. https://doi.org/10.1007/s11156-008-0090-y

Ofori, DF, Nyuur, RB \& S-Darko, MD. (2014). Corporate social responsibility and financial performance: Fact or fiction? A look at Ghanaian banks. Acta Commercii, 14(1), 1-11. https://doi.org/10.4102/ac.v14i1.180

Orij, R. (2010). Corporate social disclosures in the context of national cultures and stakeholder theory. Accounting, Auditing, \& Accountability Journal, 23(7), 868-889. https://doi.org/10.1108/09513571011080162

Orlitzky, M, Schmidt, FL \& Rynes, SL. (2003). Corporate social and financial performance: a meta-analysis. Organization Studies, 24(3), 403-441. https://doi.org/10.1177/0170840603024003910

Pesaran, MH. (2004). General Diagnostic Tests for Cross Section Dependence in Panels. IZA Discussion Paper No. 1240.

Preston, LE \& O'Bannon, DP. (1997). The corporate social-financial performance relationship. Business \& Society, 36(4), 419-429. https://doi.org/10.1177/000765039703600406

Ruf, B, Muralidhar, K, Brown, R, Janney, J \& Paul, K. (2001). An empiricalinvestigation of the relationship between change in corporate social performance and financial performance: a stakeholder theory perspective. Journal of Business Ethics, 32(2), 143-156. https://doi.org/10.1023/A:1010786912118

Senaratne, S. (2009). Corporate social responsibility reporting in Sri Lanka. Sri Lanka Journal of Humanities and Social Sciences, 1(1).

Stanwick, PA \& Stanwick, SD. (1998). The relationship between corporate social performance, and organizational size, financial performance, and environmental performance: an empirical examination. Journal of Business Ethics, 17(2), 195-204. https://doi.org/10.1023/A:1005784421547

Stanwick, SD \& Stanwick, PA. (2000). The relationship between environmental disclosures and financial performance: An empirical study of US firms. Eco-Management and Auditing, 7(4), 155-164. https://doi.org/10.1002/1099-0925(200012)7:4<155::AID-EMA137>3.0.CO;2-6

Tanweer, B, Muhammad, AK, Tahir, A, Shamila, S \& Muhhamad, AK. (2017). The Corporate Social Responsibility and Firms' Financial Performance: Evidence from Financial Sector of Pakistan. International Journal of Economics and Financial Issues, 7(2), 301-308.

Tarus, DK. (2015). Corporate Social Responsibility Engagement in Kenya: Bottom Line or Rhetoric? Journal of African Business, 16, 289-304. https://doi.org/10.1080/15228916.2015.1071998

Tilakasiri, KK. (2012). Corporate social responsibility and company performance: evidence from Sri Lanka. Doctor of Philosophy, Faculty of Business and Law, Victoria University, Australia.

Turker, D. (2009). How corporate social responsibility influences organizational commitment. Journal of Business Ethics, 89(2), 189-204. https://doi.org/10.1007/s10551-008-9993-8

Tyagi, R. (2012). Impact of corporate social responsibility on financial performance and competitiveness of business: a study of Indian firms. PhD, Department of Management Studies, Indian Institute of Technology Roorkee. https://doi.org/10.2139/ssrn.2251580

Unerman, J. (2000). Methodological issues: reflections on qualification in corporate social reporting content analysis. Accounting, Auditing \& Accountability Journal, 13(5), 667-680. https://doi.org/10.1108/09513570010353756

Van Beurden, P \& Gossling, T. (2008). The worth of values - a literature review on the relation between corporate social and financial performance. Journal of Business Ethics, 82, 407-424. https://doi.org/10.1007/s10551-008-9894-x 
Waddock, SA \& Graves, SB. (1997). The corporate social performance-financial performance link. Strategic Management Journal, https://doi.org/10.1002/(SICI)1097-0266(199704)18:4<303::AID-SMJ869>3.0.CO;2-G

Weber, O. (2017). Corporate sustainability and financial performance of Chinese banks. Sustainability Accounting, Management and Policy Journal, 8(3), 358-385. https://doi.org/10.1108/SAMPJ-09-2016-0066

Wijesinghe, KN \& Senaratne, S. (2011). Impact of Disclosure of Corporate Social Responsibility on Corporate Financial Performance in Banks, Finance and Insurance Sector in Sri Lanka. Available at: www.kln.ac.lk/uok/ICBI2011/A\&F\%20141.pdf.

Wu, MW \& Shen, CH. (2013). Corporate social responsibility in the banking industry: Motives and financial performance. Journal of Banking \& Finance, 37(9), 3529-3547. https://doi.org/10.1016/j.jbankfin.2013.04.023

Yeung, S. (2011). The role of banks in corporate social responsibility. Journal of Applied Economics and Business Research, 1(2), 103-115. 